\title{
Kan man se på et bibliotek, at det er et bibliotek?
}

\author{
Nan Dahlkild
}

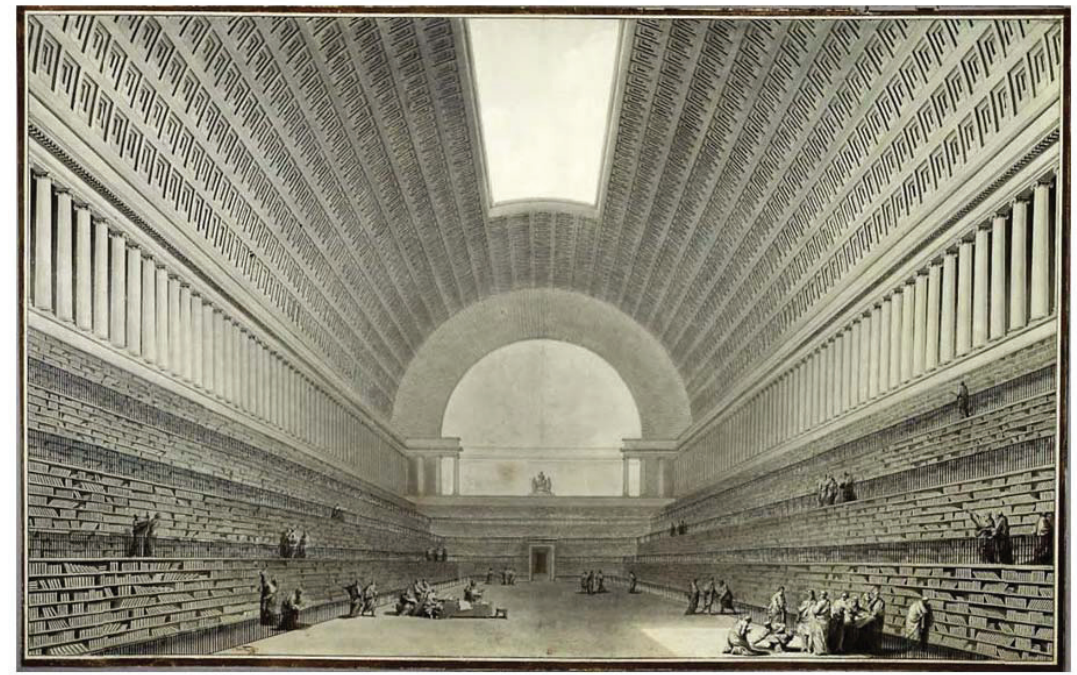

Figur 1. Etienne-Louis Boullés utopiske biblioteksprojekt fra 1785 med boggallerier og diskuterende grupper.

Man kan også stille spørgsmålet mere åbent og spørge, om biblioteker eller i bredere forstand kulturelle byggerier har et særligt arkitektonisk udtryk, som gør det muligt at afkode deres identitet i forhold til skoler, domhuse, banegårde, elværker eller andre bygningstyper? Man kan gøre spørgsmålet endnu bredere: Hvor langt kan man gå i retning at fortolke arkitekturen som udtryk for bagvedliggende kulturpolitiske intentioner? Hvor tydeligt kommer kul-

Nan Dahlkild, lektor, PhD og mag.art. Det Informationsvidenskabelige Akademi, Københavns Universitet, cwv520@hum.ku.dk turpolitiske nyorienteringer til udtryk i form af ny arkitektur?

Man kunne yderligere tilføje skiltning, grafisk identitet og logoer, som har deres egen æstetik og udvikling. Her vil der blive fokuseret på den arkitektoniske udformning og indretning i kulturpolitisk sammenhæng.

Begrebet "architecture parlante" eller "talende arkitektur" kan føres tilbage til den franske oplysningstids store projekter, hvor kulturelle byggerier fik en helt ny og vigtig placering i byens rum, og hvor gigantiske biblioteks- og museumsbyggerier med deres grupper af diskuterende grupper klædt i antikke 
gevandter repræsenterede en tidlig form for byen som scene. (Skot-Hansen, 2007) De mange projekter af bl.a. revolutionsarkitekterne Étienne-Louis Boullée og Claude-Nicolas Ledoux var tydelige forsøg på at manifestere oplysningens betydning og i de store biblioteksvisioner iklæde oplysningsideerne og den franske encyklopædis universelle viden fysisk form som videnstempler.

Samtidig med at arkitekturen var gennemført klassisk, var der andre træk i denne visionære oplysningsarkitektur, der pegede frem mod nutidige fænomener som iscenesættelse og oplevelsessamfund. Det hangarstore biblioteksrum med den enorme kassetterede loftshvælving bliver på Boullées tegning brugt som demokratisk mødested for klynger af diskuterende og gestikulerende mennesker (Fig. 1) (Pevsner, 1976, s. 103). Et andet af Boullées projekter, som var tænkt som monument for den engelske fysiker Isaac Newton, var udformet som en hul kugle med huller i muren, som svarede til stjernehimlen over den nordlige halvkugle. Fra bunden af kuglen kunne man opleve det svimlende store mørke rum og få en oplevelse som at flyve i ballon i verdensrummet (Pevsner, 1976, s. 13).

De mange projekter blev kun i begrænset omfang opført i selve perioden, men fik stor betydning som forbillede for udformningen af de kommende århundreders kulturelle byggerier. I Danmark er det oprindelige Classenske Bibliotek i Amaliegade fra
1796 et fint eksempel på sammenfaldet mellem oplysningsfilosofi og oplysningsarkitektur. Bibliotekets facade med otte rosa søjler i stor orden trådte markant frem i gadebilledet (Fig. 2). Også Universitetsbiblioteket i Helsingfors fra 1838 svarer til tidens idealer med sin centrale beliggenhed ved byens store domkirkeplads.

Det nittende århundredes store biblioteker havde typisk sakrale forbilleder: Templer eller katedraler. Fælles for udformningen af Universitetsbiblioteket i Fiolstræde i København fra 1861, Statsbiblioteket i Århus fra 1902 og Det Kongelige Bibliotek i København fra 1906 var forbilleder fra kirkearkitekturen (Dahlkild, 2015, s. 64-74). Stilen var en fri historicisme med anvendelse af røde teglsten og righoldig symbolsk udsmykning, som udtrykte oplysningens betydning, bibliotekernes universelle karakter, nationale kendemærker og de enkelte fags symboler.

Universitetsbiblioteket, tegnet af Johan Daniel Herholdt, var præget af både historiske forbilleder og moderne konstruktioner (Fig. 3). Tydelig var inspirationen fra middelalderlige kirker både i bygningens basilikaformede grundplan og i facadens røde mursten med romanske og gotiske detaljer, især inspireret af Herholdts skitser fra kirker i Verona. Moderne træk var de store, næsten sammenhængende vinduesarealer, støbejernskonstruktionerne i bibliotekets indre og tænkningen i moduler. Det blå stjerneloft i bibliotekssalen understreger bibliotekets sakrale og

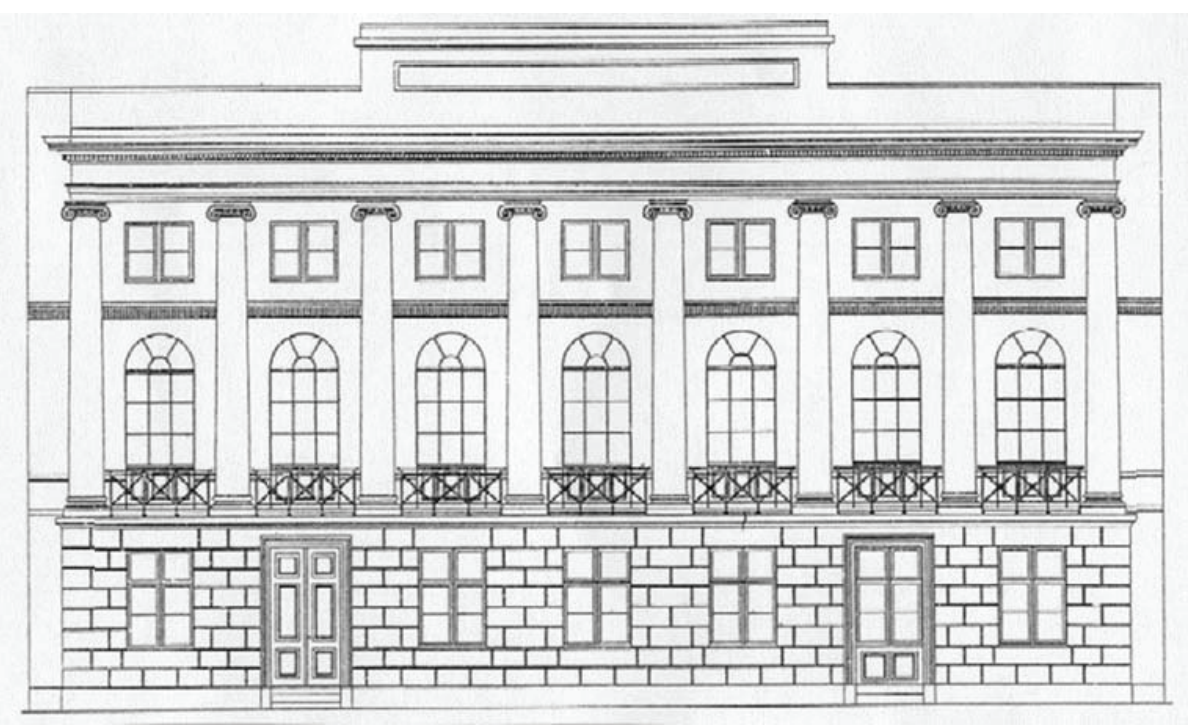

Figur 2. Det Classenske Bibliotek fra 1786 med 8 joniske søjler. 


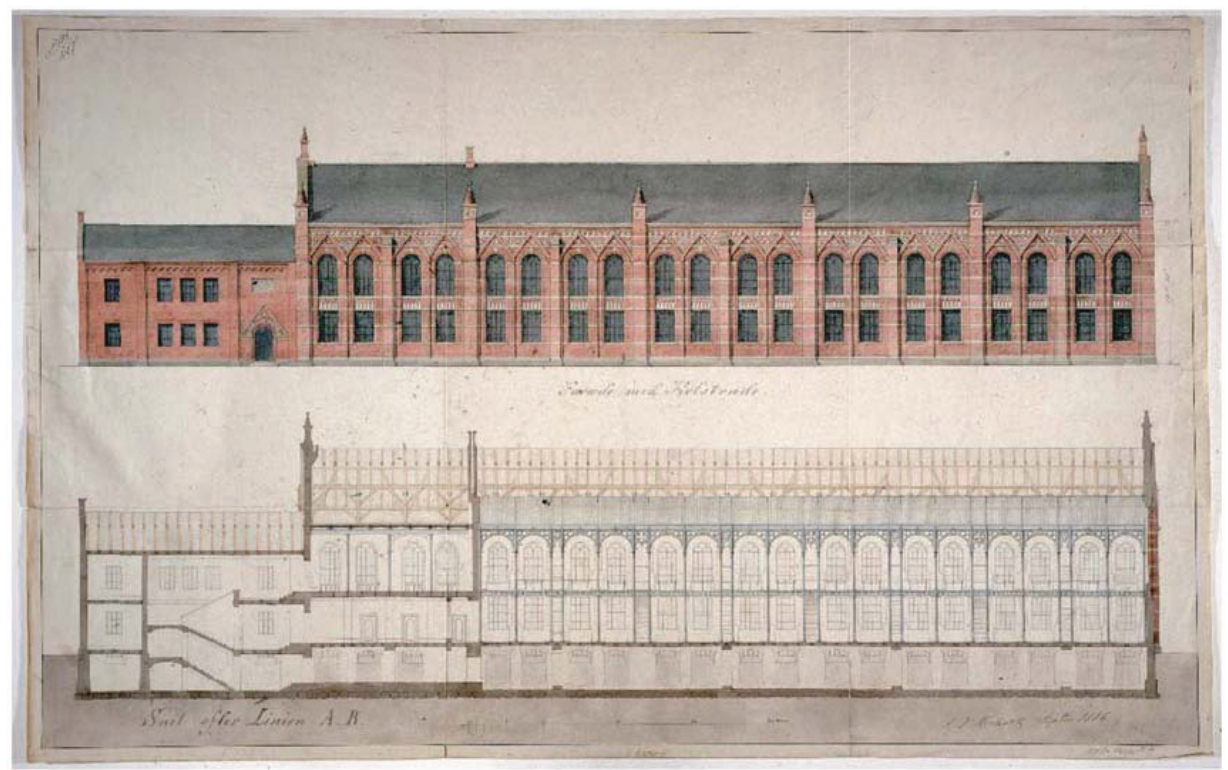

Figur 3. Universitetsbiblioteket fra 1861 som bibliotekskatedral.

universelle karakter. Gavlens store rosetvindue og de farvede glasruder skaber ligeledes oplevelse af et kirkerum. Den hurtigt forbipasserende kan i farten opleve bygningen som en kirke, men gennem de store transparente glasvinduer ud mod Fiolstræde med kig til de mange farvede bogrygge ser man biblioteket som bibliotek.

Både det ydre og det indre af det oprindelige Statsbibliotek i Århus, tegnet af arkitekten Hack Kampmann, blev rigt dekoreret og har givet anledning til betegnelsen "Hack Kampmanns smykkeskrin". På hovedfacaden blev universaliteten i tid og rum markeret af de tolv stjernetegn. Bibliotekets indre var præget af billedhuggeren Karl Hansen Reistrups tre store lysekroner, båret af snore spundet af seks edderkopper under glaskuplerne. De blev udformet som insekter med røde, gule, blå og grønne sten og edderkoppespind af glasperler. Bibliotekets gesims blev befolket af kloge ugler: Biblioteket som kundskabens hus. De mange naturlige og organiske dekorationer svarede til tidens Art Nouveau. Biblioteket var både smykkeskrin og bogskrin.

Også Det Kongelige Bibliotek bygning kan aflæses som et stort nationalt forskningsbibliotek. Indgangspartiet markeres af de to tårne med balkoner og spirene med kongekroner. På facaderne er der medaljoner med symbolske fremstillinger af fagene $\mathrm{i}$ videnskabernes kreds. Bibliotekets centrale rum ud- gøres af den basilikaformede læsesal med seks blanke granitsøjler i hele rummets højde, hvide hvælvinger og plads til ca. 100 brugere. Søjlernes kapitæler blev udsmykket med blomster, ugler og fakler, som dels svarede til skønvirkeperiodens dekorationer, dels symboliserede vækst, visdom og oplysning. Det Kongelige Bibliotek var og er Danmarks største magasinbibliotek. Bygningens magasinkarakter svarer til de oprindelige funktioner for de omgivende bygninger Proviantgården og Tøjhuset. De store magasiner lever op til biblioteksbegrebets betydning som "boglager".

I modsætning til disse spektakulære byggerier var tidens folkebogsamlinger næsten usynlige og helt uden iscenesættelse. De kunne ligge i en lejlighed i en sidegade eller rummes i en reol i præstens eller skolelærerens stue. En forædlet udgave af den lille folkebogsamling i den lille by var det arbejdende udstillingsbibliotek, der blev opført sammen med en forsamlingsbygning som en del af Stationsbyudstillingen på Landsudstillingen i Århus i 1909 (Dahlkild, 2011, s. 116-121). Dette lille "kulturcentrum" var led i en samlet arkitektur- og kulturpolitisk manifestation, som skulle fremme folkeoplysningen ved at inspirere Landsudstillingens gæster til at bygge bedre stationsbyer, oprette nye biblioteker og fremme læsningen af gode bøger. 
Bygningen fik med sin størrelse og det lille foranliggende haveanlæg en fin placering på stationsbyens hovedgade. Den blev udformet som en vinkelbygning, hvor biblioteket havde til huse i den korte fløj, mens forsamlingssalene lå i den lange fløj, næsten som en tolænget gård på landet. Det lyse biblioteksrum var møbleret med borde, stole og reoler af fyrretræ og holdt i gule, grønne og brune farver. Det hjemlige præg understregedes af fraværet af en egentlig skranke.

Efterfølgende fik udstillingsbiblioteket betydning for oprettelsen af bl.a. Vejen Bibliotek, som blev indrettet $i$ en landlig villa med have og med stuer med kamin og malerier på væggene næsten som i et privat hjem. Skranken mindede om et almindeligt skrivebord med læselampe. I en af stuerne var der mulighed for ar spille brætspil. Desuden kom Bedre Byggeskiks enkle stil til at præge en række af tyvernes biblioteksbyggerier som f.eks. Grenå, Sakskøbing, Halvrimmen og Løgstør. Her lå bibliotekerne som almindelige huse i gadebilledet. Hvis der ikke var noget skilt, eller man ikke vidste det i forvejen, kunne man ikke umiddelbart se, at her var et bibliotek. Den beskedne og traditionelle arkitektur signalerede tilknytning andelsbevægelse, højskoler og grundtvigianisme. Den hjemlige karakter stod i modsætning til periodens voksende institutionspræg, som kom til udtryk i både betjening og indretning.

Typisk for udbygningen af folkebibliotekerne i mellemkrigstiden var det lille "videnstempel", "oplysningstempel" eller "bogtempel", hvor bibliotekerne ligesom samtidens museer typisk fik en ophøjet klassicistisk udformning (Dahlkild, 2011, s. 149-160). H.O. Lange talte allerede før krigen om et "Tempel for Aandslivet". Arkitektonisk var videnstemplet forbundet med tidens nyklassicisme, men historisk lå det i forlængelse af både den franske oplysningsarkitekturs fornuftstempler og de amerikanske Carnegie biblioteker fra tiden omkring 1900. Begrebet har dog også en dybere arkitektonisk og intellektuel betydning, som kan føres tilbage til antikkens templer som skrin for gudernes hellige skatte eller til Det gamle Testamentes Salomons Tempel. Fælles for nyklassicismen og senere modernismen var en "ny saglighed", som forbandt de to retninger i flere offentlige byggerier.

Idealtypisk for videnstemplet var en symmetrisk grundplan, formet som en "sommerfugl" med ind- gang og voksenudlån placeret i midteraksen som "krop" og voksenlæsesal og børnebibliotek på hver side som "vinger". Ofte forbandt midteraksen biblioteket og dets omgivelser. Den klassicistiske monumentalitet understregedes yderligere af høje trapper, der førte op mod et fremhævet indgangsparti. Symmetrien fortsatte ind i forhallen og derfra videre ind i voksenudlånet til skranke eller bibliotekarbord. Det centrale kortkartotek med registreringen af bibliotekets samlinger og typisk et ur for endevæggen var ligeledes placeret i midteraksen og markerede orden i de universelle samlinger, i tid og rum. Som videnstempel repræsenterede folkebiblioteket den lille universalsamling.

Videnstemplet markerede en tydelig sammenhæng mellem arkitektur, indretning og organisering af kultur og viden. Institutionaliseringen af folkebibliotekerne kunne føres tilbage til Biblioteksloven fra 1920, og som type anbefaledes sommerfugleplanen i forskellige variationer i lærebøger og anmeldelser. Den blev en konvention, som blev fulgt af tidens arkitekter. Typiske videnstempler var Hjørring Bibliotek fra 1927 og det stadig fungerende Frederiksberg Bibliotek fra 1935. Begge markerede sig i bybilledet med ophøjet beliggenhed, fremhævet indgangsparti og symmetri.

Videnstemplerne udgjorde kernen i mellemkrigstidens biblioteksbyggeri. Folkebibliotekerne rykkede fra sidegadernes små hjemlige læsestuer frem til større og mere selvstændige bygninger om end ikke ved hovedgaden, så dog med en mere central beliggenhed eller med mere plads på større grunde i byernes udkanter.

Det kan dog synes paradoksalt, at en bevægelse og et væsen, som med sine åbne hylder understregede værdier som demokrati, folkelighed og åbenhed, netop indrettede sig i lukkede, ophøjede og tempelagtige bygninger med højt placerede vinduer. En forklaring kan være ønsket om at markere bibliotekernes oplysningspolitiske betydning og dermed iscenesætte ambitionerne om en vigtig samfundsmæssig placering. Til videnstemplernes kvaliteter hørte deres genkendelighed, regularitet, klare funktionsopdeling, gode pladsforhold og luftige lokaler med højt til loftet. Mellemkrigstidens biblioteksbyggeri blev ikke præget af den hvide modernisme eller arkitektoniske eksperimenter, der kunne tolkes, som om folkebibliotekerne ikke var for alle, men derimod af en mo- 
derniseret og mindre monumental klassicisme. Den senere biblioteksdirektør Robert L. Hansen skrev om Thisted Biblioteks enkle klassicisme fra 1938, at den var " i Pagt med Tidens Aand, uden paa nogen Maade at virke udfordrende paa den jævne Beskuer" (Bogens Verden, 1938, s. 167).

Dertil skal føjes, at årene efter 1. Verdenskrig var præget af en klassicistisk orienteret arkitektur med vægt på nøgternhed, symmetri og monumentalitet, som kom til at kendetegne tyvernes danske arkitektur fra rådhuse, skoler, museer, biblioteker, sportsanlæg, posthuse, stationer og elværker til boligkarreer, villaer, sommerhuse, kiosker og benzintanke. Mange af disse bygninger blev udformet som små templer.

Lige før krigen ændrede udviklingen karakter, og med opførelsen af Nyborg Bibliotek i 1939, tegnet af Erik Møller og Flemming Lassen, blev der skabt en ny bibliotekstype som udtryk for ønsket om demokratisering af folkeoplysningen og forestillingen om "kulturen for folket" (Fig. 4). Med sin åbne og imødekommende udformning, de nemme adgangsforhold, de varierede rumlige forløb og indretningen med lette og lyse træmøbler brød det med tidens mere monumentale kulturelle byggeri.

Indgangen var en enkel glasdør i den lave glasgang, der forbandt bygningens to fløje. Det underspillede indgangsparti med grønne planter var bemærkelsesværdigt i forhold til tidens mere monumentale trapper og høje døre. Glasgangen forbandt som et væksthus ude og inde, natur og kultur. Biblioteks- rummet fortsatte ud i bibliotekshaven gennem en hvid pergola.

Vinduer i øjenhøjde forbandt bibliotekets rum med omgivelserne og var ligeledes et brud med periodens mange høje vinduesplaceringer over reolerne. Væggene i udlån og læsesale var beklædt med lyse paneler af ahorn fra gulv til loft. Møblerne var traditionelle typer i forenklede udgaver, som pegede frem mod den serie af brugervenlige og folkelige dagligstuemøbler, som den danske brugsforeningsbevægelse satte i produktion efter 2. Verdenskrig som en form for praktisk folkeoplysning.

Nyborg Bibliotek har senere fået en ganske særlig placering inden for dansk arkitektur og fremhæves i arkitekturhistoriske fremstillinger. I samtiden var meningerne delte. I tidens optik lignede biblioteket ikke umiddelbart et bibliotek. I en anmeldelse i en af de lokale aviser stod der, at biblioteket kunne minde om en almindelig lade. Fagtidsskrifterne var derimod uhyre positive, og en ung gymnasieelev oplevede biblioteket som lyst og moderne, men også som en del af stedets ånd: "I 1940 kom jeg næsten dagligt i det hyggelige biblioteks læsesal, hvor vi var en kreds af gymnasiaster, der mødtes. Bibliotekets indre var lyst, roligt og smukt med lyse reoler, som var lette at overse. Praktiske møbler i læsesalen - man følte sig godt tilpas der. Jeg husker, at jeg følte det, som om biblioteket altid havde ligget der. Det lå, som om det var "groet" op der" (Dahlkild, 2011, s. 180).

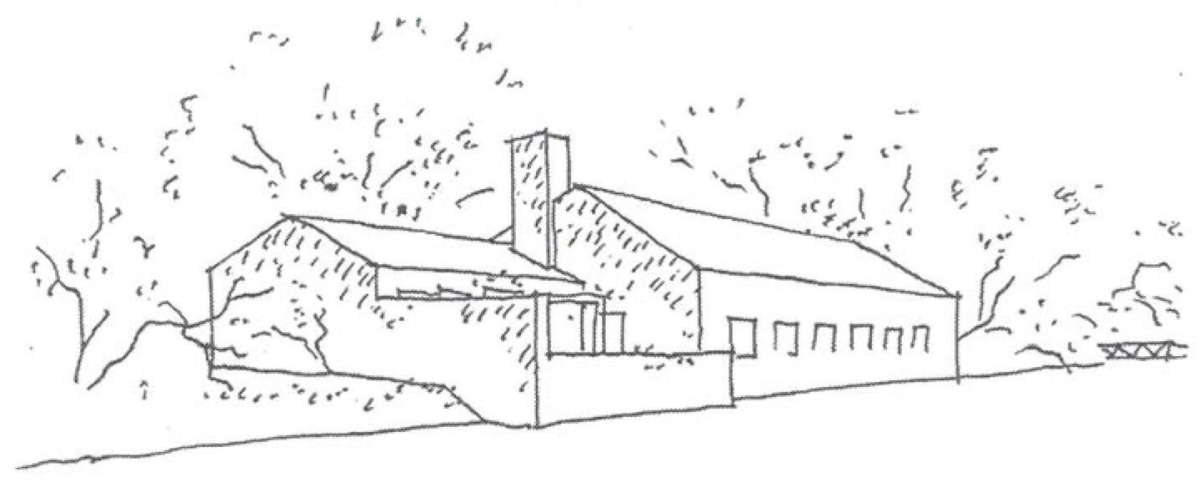

SET FRA SLOTSBROEN

Figur 4. Skitse til Nyborg Bibliotek fra 1939 som det beskedne hus, der brød med videnstemplerne som udtryk for "kulturen for folket". 
I 1964 vedtoges en ny bibliotekslov, som bl.a. gav bibliotekerne mulighed for at inddrage nye medier og selv tage initiativ til kulturelle arrangementer. Sammen med kommunalreformen i 1970 gav loven anledning til et stort nyt biblioteksbyggeri, som var præget af tidens modernisme med mantraer som "bredt, lavt og fladt" og "ingen spærrende vægge, ingen besværlige trapper, ingen lukkede døre". Samtidig blev forestillinger om kulturcentre en vigtig del af kulturdebatten og velfærdssamfundets kulturpolitik. I forhold til de foregående årtiers vægt på folkeoplysning blev vægten i højere grad lagt på kreative og kunstneriske aktiviteter.
Rødovre Bibliotek fra 1970 af Arne Jacobsen er et eksempel på det nye kulturelle byggeri, som hørte sammen med velstandsstigningen og forstadsudviklingen i tiårene efter krigen (Fig. 5) (Dahlkild, 2013, s. 157-161). Det var også eksempel på tidens minimalisme, men ikke i samme transparente form som tidens øvrige biblioteksbyggeri. Biblioteket ligger som en lav kompakt bygning, omgivet af en perimetermur af sorte norske naturkvadre uden vinduer. På afstand kan man se det næsten svævende tag over bibliotekssalen, kun båret af fire slanke søjler. Især om aftenen træder salen, når den er belyst, tydeligt frem med det hvide svagt hvælvede tag over den omgivende mur.

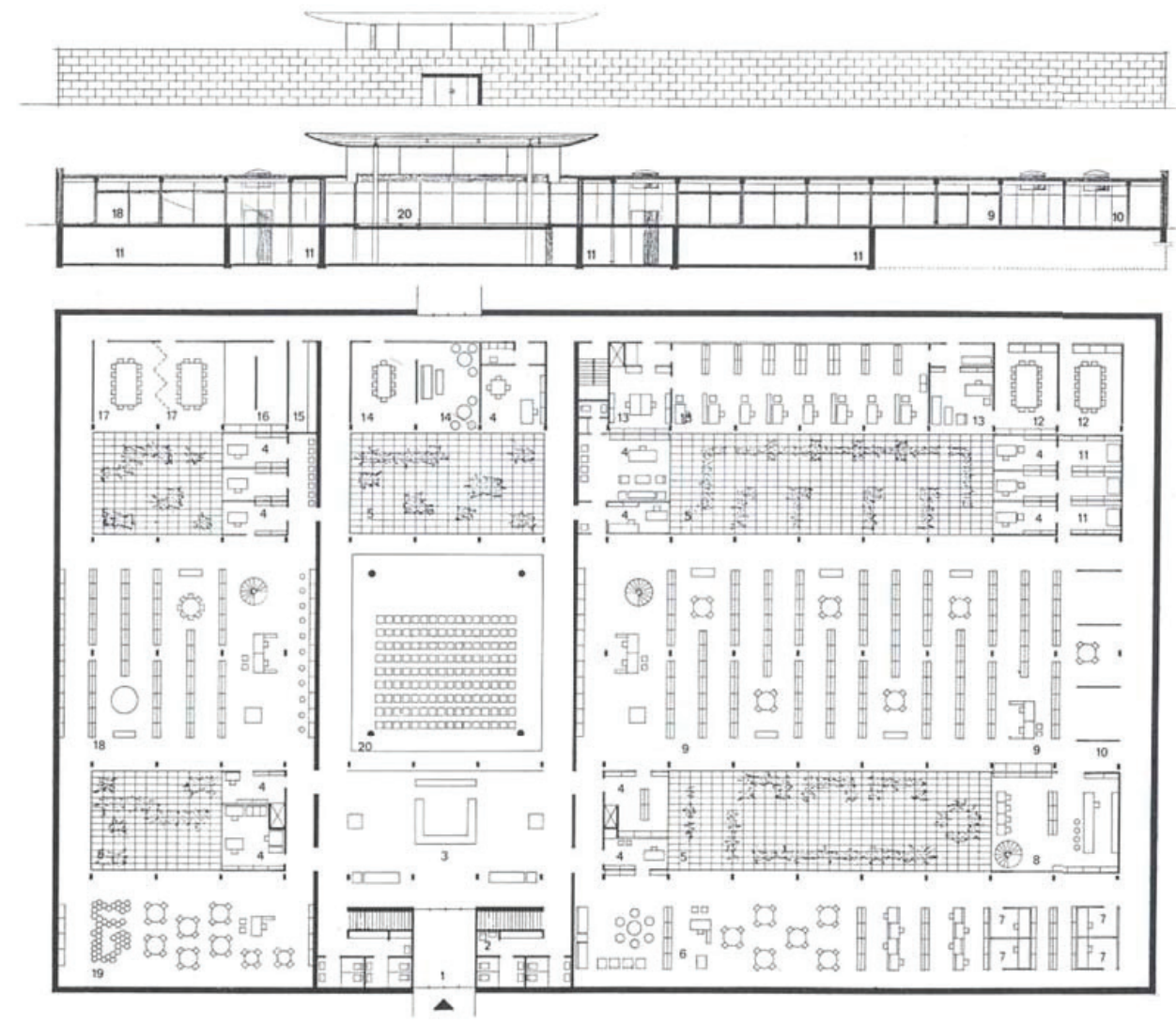

\section{aktiviteter.}

\footnotetext{
Facade, snit og plan, màl $I: 400$

$I$, vindfang. 2 , toilet for handicappede. 3 , forhal med falles skranke.

4, kontor. 5, gårdhave. 6, lasesal for voksne. 7, studieceller.

8 , diskotek. 9, udlân for voksne. IO, pinakotek. II, magasin.

12 , studiekredsrum. 13 , katalogafdeling. 14 , personalerum. 15 , kөk-

ken. 16 , scene. 17 , studiekreds- og eventyrrum. 18 , udlän for born.

19 , lasesal for born. 20, foredragsal.
}

Figur 5. Grundplan for Rødovre Bibliotek fra 1970. På planen ses den oprindelige møblering med den serielle, retvinklede reolopstilling, der senere er opgivet af hensyn til nye formidlingsformer. 
Den retvinklede ydre orden gik igen i den indre orden, både rumligt og møbleringsmæssigt. Voksenudlånets serielle opstilling af parallelle reoler med samme afstand og højde svarede til modernismens rationelle idealer for både byplanlægning, byggeri og indretning. Byplanens rette linjer og serielle karakter fortsatte ind i udlånsalens rækker af reoler. Samtidig svarede opstillingen af bøger og reoler til den universelle orden i bibliotekernes fortløbende decimalklassedeling. Voksenlæsesalen og børnebiblioteket var møbleret med tilsvarende orden, for børnebibliotekets vedkommende dog med små udgaver af Arne Jacobsens møbler. Et særligt legelandskab, hvor børnene kunne sætte sig i forskellige afsatser og højder, var karakteristisk for periodens møbleringsmæssige eksperimenter.

Et paradoks i de nye kulturcentre var forholdet mellem de mange eksperimenterende aktiviteter og den rationelle, modulorienterede og ofte næsten anonyme arkitektur. Både de mange kreative aktiviteter og eksperimenterende udstillinger var præget af modernismens kunstopfattelse i retning af abstraktion og ekspressive udtryk. Arkitekturen lå derimod i forlængelse af tidens internationale minimalisme. Kunst og arkitektur kom derved til at repræsentere forskellige sider af modernismen. Ligesom kulturcentrene var det kunstneriske og rekreative element $i$ tidens lineære og rationelle byplanlægning, udgjorde de åbne arrangementer, kunstudstillingerne og legelandskaberne det kreative indhold, der udfyldte rammerne i flere af de minimalistiske og stramt planlagte byggerier.

Rødovre Bibliotek har givet anledning til mange fortolkninger og synspunkter fra stor værdsættelse af det arkitektoniske udtryk til kritik af den manglende gennemskuelighed. Bygningen er ofte blevet karakteriseret som mausulæumsagtig og lukket, så den ikke svarer til folkebibliotekernes åbenhed. På den anden side er den også blevet sammenlignet med en bog, der åbner sig, når man læser den, svarende til bibliotekets indre gårdhaver og den lyse bibliotekssal.

Under alle omstændigheder har der været problemer med at aflæse biblioteket som bibliotek. Bygningen var oprindelig uden skiltning, bortset fra et lille metalskilt ved siden af indgangen, næsten som et skilt foran en skulptur. Netop den manglende skiltning og den fraværende signalværdi som bibliotek, som var typisk for minimalismens arkitektoniske udtryk, gav anledning til kritik, bl.a. i biblioteksfaglig sammenhæng.

Bibliotekstidsskriftet Bogens Verden bragte en kortfattet anmeldelse i form af en billedtekst til et fotografi af biblioteket og rådhuset. Den roste det lyse og venlige interiør med afstemte farver, men sluttede: "Men mens rådhuset åbner sig udad med store glasfacader, er biblioteket lukket inde bag en ubrudt, sort marmor-mur, som intet røber om den virksomhed, der udfolder sig indenfor. Ved vejen oplyser et beskedent skilt om bibliotekets tilstedeværelse. Fristende - og nok så effektivt - ville det være at udstyre den sorte murflade med meterhøje hvide bogstaver: BIBLIOTEK" (Bogens Verden, 1970, s. 169).

Som konsekvens af den manglende aflæselighed som bibliotek opsattes i efteråret 1977 store bogstaver med teksten RØDOVRE KOMMUNEBIBLIOTEK på facaden ud mod Rødovre Parkvej. Den konkrete anledning var, at Foreningen Norden og biblioteket havde inviteret til en foredragsaften med den kendte svenske TV-journalist Lasse Holmquist. Der var pænt fremmøde med Rødovres daværende borgmester Dahl-Nielsen i spidsen. Lasse Holmquist lod dog vente på sig, og der gik 20 minutter, før hans taxa fandt vej til bibliotekets indgang. Den havde da kørt frem og tilbage på Rødovre Parkvej i mere end en halv time. Efterfølgende fik stadsarkitekten besked på at opsætte et skilt på bibliotekets gavl, synligt både dag og nat.

Et af de store internationale forbilleder for udviklingen af kulturcentre var Centre Pompidou i Paris, som stod færdigt i 1977 (Fig. 6). Det er tegnet af arkitekterne Renzo Piano og Richard Rogers og opkaldt efter tidligere præsident Georges Pompidou. Centeret, der er på 100.000 kvadratmeter og 7 etager, indeholder flere kulturelle institutioner, som kan besøges samlet. På de tre nederste etager ligger biblioteket, som også omfatter samlinger af plakater og film. I bygningens ydre er en fast facadebeklædning erstattet af synlige bærende konstruktioner og tekniske installationer. En ydre rullende trappe slanger sig langs facaden. De store synlige rør på bygningens modsatte side var oprindelig kodet i forskellige farver: Ventilationsanlægget blev malet blåt, vandrør grønne, elevatorer og rullende trapper røde og elektriske kabler gule. High tech stilen brød med mere traditionelle kulturelle byggerier med fabrikken eller olieraffinaderiet som forbillede. Som Renzo Piano har udtrykt 


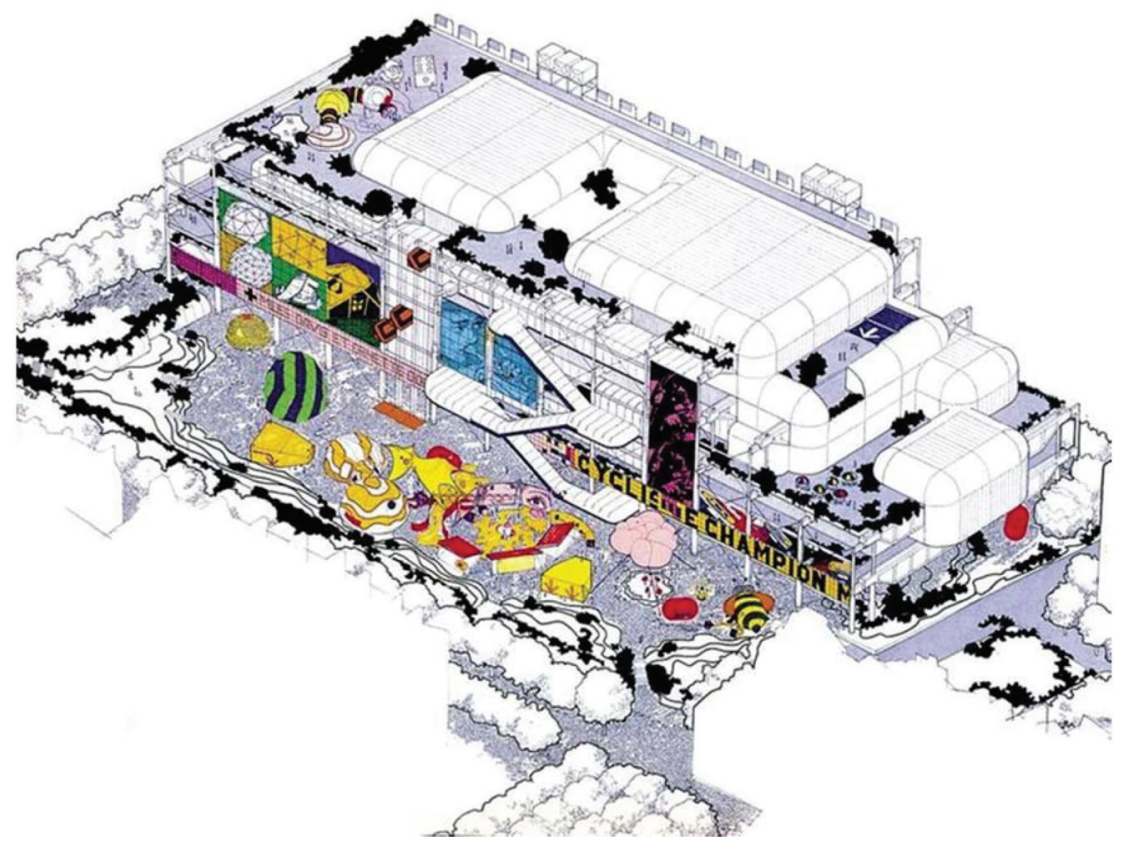

Figur 6. Tidlig tegning til Centre Pompidou i Paris med bløde tresserformer.

det: "Bygningen er ikke tænkt som monument, men som en fest, et kæmpe urbant legetøj" (Skot-Hansen, 2013, s. 204). Centeret har siden fået status som kulturelt og arkitektonisk ikon. Det kan genbesøges og spiller stadig sammen med det mangfoldige liv på pladsen foran centeret og de mange øvrige kulturelle aktiviteter i Paris (Skot-Hansen, 2013, s. 213).

Også i Danmark gik udviklingen i retning at inddrage biblioteket i byens rum. Som eksempler på biblioteker som dele af bycentre sammen kan nævnes Medborgerhuset i Ålborg med rådhus og bibliotek fra 1980 og kulturhuset i Holstebro fra 1981, som lå i forlængelse af kommunens aktive kulturpolitik (Skot-Hansen, 1998). Begge steder blev biblioteket tænkt ind i et offentligt byrum og fik dermed en social og urban dimension ud over den funktionelle opstilling af samlingen.

De små vinduer i Medborgerhusets ydre og indre mure var indfattet af samme type betonelementer, således at facaderne fortsatte som husrækker ind i bygningen. Et lille trekantet torv ledte hen til indgangen til biblioteket, og en indre gade førte ind til bibliotekets store udlånssal, der i sig selv var udformet som et stort bibliotekstorv. Omkring dette torv var alle bibliotekets aktiviteter grupperet. Det sammenbyggede rådhus og bibliotek i Holstebro var udformet efter samme principper (Fig. 7). I det ydre havde bygnin- gen præg af middelalderborg med massivt murværk, fremhævede fugninger og tårnagtige fremspring, og i det indre var det rustikke inventar og den næsten armerede belysning gjort yderligere robust. Et indvendigt torv forbandt rådhuset og biblioteket. Den store trappe i den centrale sal gav associationer til en middelalderby. Arkitekterne Dall \& Lindhardtsen havde borgen som motiv. Anmeldelserne fremhævede de store murmasser, de robuste materialer og de indre torve som demokratiske rum under overskrifter som Borgerglaeder og En borg fuld af bøger (Bogens Verden 1980:9, s. 513-517 og Bogens Verden, 1981:8, s. 548-551).

Denne interesse for biblioteket som en del af byrummet er blevet yderligere forstærket i flere biblioteksbyggerier omkring årtusindskiftet, hvor biblioteker internationalt og i Danmark er tænkt ind i byfornyelse og kvarterløft som både arkitektoniske ikoner, som økonomiske igangsættere og som sociale, uddannelsesmæssige og kulturelle aktører i forbindelse med byfornyelse af problemområder. Som eksempel på det sidste kan nævnes forskellige initiativer i London, både i form af de såkaldte "idea stores" med et helt nyt biblioteksbegreb og biblioteket i Peckham som et stykke avantgarde-arkitektur i et nedslidt kvarter i det sydlige London. 


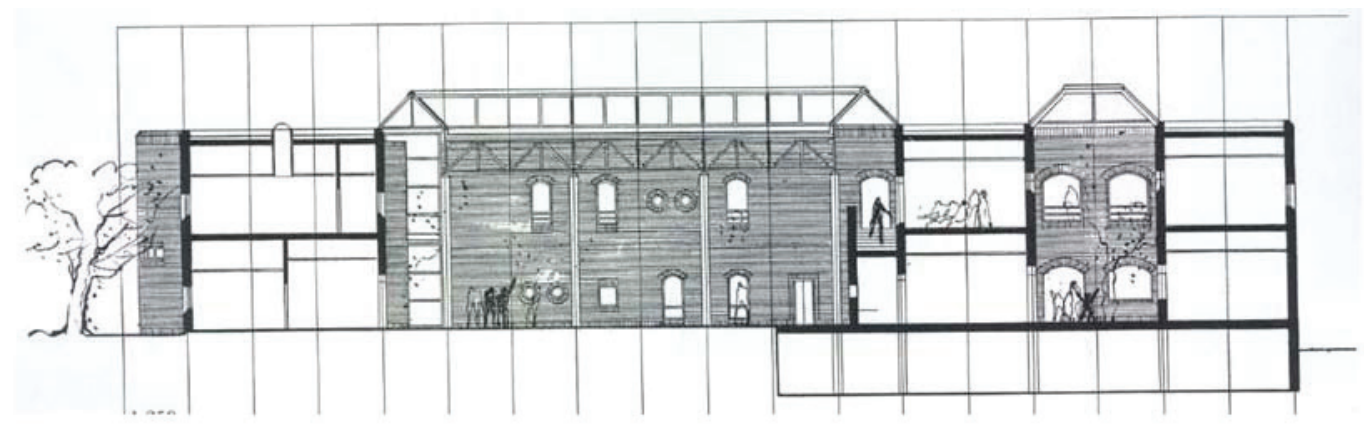

Figur 7. Snit gennem Holstebro Bibliotek med den indre borggård.

Kvarterhuset i Holmbladsgade på Amager kan nævnes som et lignende dansk eksempel på bibliotekets betydning i forbindelse med kvarterløft og lokal udvikling (Hvenegaard Rasmussen, Jochumsen og Skot-Hansen, 2011). Et andet dansk eksempel er biblioteket og kulturhuset med de gyldne kuber på Rentemestervej i Københavns robuste nordvestkvarter, som indeholder både bibliotek, borgerservice, café, lokaludvalg, værksteder, lokal-TV/lokalradio og medborgercenter. Det har sin egen identitet og spænder over kontrasten mellem store åbne rum og små nære steder som cafeen, grotten med børnebiblioteket og afdelingen for skønlitteratur. Facaden er dækket af gyldne perforerede metalplader og store glasvinduer med udsigter udefra og ind. Udsmykningen med læsende og musicerende lånere fortsætter ind i kulturhusets foyer, der åbner sig som en indre gade. Sorte metaltrapper fører videre til de øvre etager, og i højden er der gangbroer. Den gyldne biblioteksbygning består af 4 bokse - eller 4 bøger med hver sit indhold - der er lagt oven på hinanden.

Overordnet er udviklingen især i de seneste årtier gået i retning af et bredere og mere flydende biblioteksbegreb, og tilsvarende er der sket en frisættelse af biblioteksarkitekturen og biblioteksindretningen i retning af kulturhuse med mange forskellige aktiviteter og oplevelser. Denne udvikling gælder også andre kulturelle byggerier som f.eks. museer. Ud over en friere og mere skulpturel arkitektur er logoer og navne blevet bredere og mere originale: Vanløse Bibliotek er blevet til Kulturstationen, Helsingør Bibliotek til Kulturværftet, Århus Bibliotek til Dokk1og Århus Kunstmuseum til AROS.

Begreber som mødested og oplevelse er dog ikke nye, men kan føres tilbage til oplysningsprojektets start. Selv om biblioteker har iklædt sig mange for- skellige arkitektoniske forbilleder i form af templer, katedraler, borge eller fabrikker, har bogen været et tilbagevendende element som både synligt materiale og metafor og har gjort biblioteket umiddelbart aflæseligt som bibliotek. Den transparente arkitektur fra modernismen og fremefter giver mulighed for at se udefra og ind og indefra og ud: Se ind i de oplyste læsesaloner en mørk vinteraften og ud på trafikken, de forbipasserende og livet i lokalsamfundet.

Kulturpolitisk har bibliotekerne fået stadig bredere målsætninger og stadig flere funktioner, som kan aflæses ud fra større variation af arkitektur og indretning. Tilsvarende har mange nye biblioteksbyggerier og kulturhuse fået iøjnefaldende placeringer ved centrale pladser og havnefronter og er blevet en del af byrummets iscenesættelse.

Det sete afhænger af øjnene, der ser. Mange af bygherrernes kulturpolitiske intentioner er utvivlsomt blevet forstået bevidst eller ubevidst og kan stadig afkodes. Det gælder både de forskellige perioders kultursyn, biblioteksbegrebets forandringer og forskellene mellem de forskellige bygningstyper.

I 1926 skrev Kritisk Revy polemisk om tidens mange stilarter: "Man kan altid se på en facade, hvad huset indeholder, men kan desværre ikke altid stole på sit syn". Det kan være værd at se efter.

\section{Referencer}

Dahlkild, N (2011). Biblioteket i tid og rum. Arkitektur, indretning og formidling. København: Danmarks Biblioteksforening.

Dahlkild, N (2013). Velfcerdens spydspids. Tressernes kulturcentre og kulturpolitiske visioner. Ar- 
chitectura, 35. København: Selskabet for Arkitekturhistorie.

Dahlkild, N (red.) (2015). Huse der har formet os. Arkitekturhistorien bag danskernes institutioner og offentlige rum. København: Museum Tusculanums Forlag.

Hvenegaard Rasmussen, C, Jochumsen, H og SkotHansen, D (2011). Biblioteket i byudviklingen - oplevelse, kreativitet og innovation. København: Danmarks Biblioteksforening.

Jørgensen, C (1946). Danske Biblioteksbygninger. København: Folkebibliotekernes Bibliografiske kontor.

Pevsner, N (1976). A History of Building Types. London: Thames and Hudson.

Skot-Hansen, D (1998). Holstebro i Verden - Verden i Holstebro. Kulturpolitik og - debat fra tresserne til i dag. Århus: Klim.

Skot-Hansen, D (2007). Byen som scene - kultur og byplanlagning $i$ oplevelsessamfundet. København: Bibliotekarforbundet.
Skot-Hansen, D (2013). Fransk kultur i undtagelsestilstand - franske kunst- og kulturarenaer $i$ en digital cera. Nordisk Kulturpolitisk Tidsskrift, 16:2, s. 201216.

\section{Illustrationer}

Figur 1. Pevsner, N (1976). A History of Building Types. London: Thames and Hudson, s. 103.

Figur 2. Danmarks Kunstbibliotek. Samlingen af Arkitekturtegninger.

Figur 3. Danmarks Kunstbibliotek, Samlingen af Arkitekturtegninger.

Figur 4. Danmarks Kunstbibliotek, Samlingen af Arkitekturtegninger.

Figur 5. Arkitektur DK, 1970:4, s. 138.

Figur 6. Richard Rogers. Complete Works. Volume One, 1999.

Figur 7. Arkitektur DK, 1981:8, s. 312. 